\title{
Circumstances Probing Internet Banking Users to Use Alternative Channels: Thematic Matrix Display Analysis
}

\author{
Sujana Adapa \\ University of New England Armidale, Australia \\ sadapa2@une.edu.au
}

\begin{abstract}
This study highlights the circumstances that actually probe internet banking users to switch to the use of alternative channels in performing their banking transactions within Australian context. Data obtained from 372 internet banking users was analysed by employing thematic matrix analysis technique to identify various macro and micro thematic categories in that hierarchical order of importance. Results revealed factors such as 'unable to perform over the internet', 'lack of internet access', 'not sure of something', 'problem rectification', 'proximity to auxiliary facilities' and 'type of internet connectivity' were relevant in identifying the circumstances under which they preferred to use other banking channels. The study provides important implications for the formulation of effective service delivery channel management strategies by way of implementing effective mechanisms. Moreover, the study also outlines important guidelines for practical solutions in order to reduce the impact of situational barriers thus focusing on effective customer retention strategies. With the information provided by this research, bank executives, consultants and academics will have enhanced knowledge of the service areas they need to focus on to improve customer satisfaction, retention and profitability in the financial services businesses.
\end{abstract}

Keywords: Internet Banking, Australian Consumers, Alternative Banking Channels, Qualitative Data Analysis, Thematic Matrix Display Analysis

\section{Introduction}

Businesses that exist today are quite different from traditional ones due to the impact of forces such as technological innovations, globalisation, financial deregulation, privatisation etc., (Mia et al. 2007). Modern businesses are also utilising technological advancements to the maximum extent possible in order to make their services more accessible to consumers (Reid, 2008; Winch \& Joyce, 2006). One such business entity is the retail banking sector that has been using a wider array of information systems to satisfy its customers ever changing needs (Wresch \& Fraser, 2006). The retail banking industry realised that relying exclusively on the traditional price factors for competition in order to increase revenue and market share in the industry may not provide long-term success (Durkin et al. 2008). Modern retail banks operating within the nexus of technology and consumers also realised that the two largest expenses incurred by banks are associated with the maintenance and overhead costs of branch networks and their associated human resources (Durkin, 2004). Therefore, banks started to realise that relying on non-price factors provided alternative strategies for differentiation, gaining competitive advantage and cost cutting (Daniel, 1999). As such, the financial services industry has become much more competitive over the last decade (Thornton \& White, 2001). In an intensifying competitive environment, superior distribution strategies relating to how to communicate with, and deliver products to, the customer effectively provides a comprehensive advantage to the banking institutions (Keremet al. 2003). Moreover, customers are also demanding greater convenience and accessibility, as reflected in longer branch opening hours and an increase in the choice of service delivery mechanisms.

On a global scale, many banks have started to set in place more cost-effective alternative service delivery systems (Shih \& Fang, 2004). The trend has seen the proliferation of multiple service delivery channels through which consumers can interact with banks. Therefore, modern banks provide their consumers with increased channel choice that reaches out to consumers through many different routes (Adapa, 2010). Alternative service delivery systems such as Automated Teller Machines (ATMs), telephone, internet and wireless channels are now available to the consumers to perform their banking transactions in addition to the traditional branch banking (Reid, 2008; Akinci et al. 2004). It has been widely accepted that internet banking is possibly the most cost-effective channel for providing electronic banking services and products efficiently to prospective customers (Giglio, 2002; Robinson, 2000). However, there are marketing and management issues that arise from relying on such new and different distribution channels. 


\section{Literature Review}

Deployment of retail or wholesale banking services involving individual and corporate clients, bank transfers, payments and settlements, documentary collections and credits, corporate and household lending and card businesses over the internet is often referred in the existing literature as internet banking (UNCTAD, 2002). For the purpose of the present research, internet banking is identified as the act of conducting financial mediation on the internet (VanHoose, 2003). Also, it has been estimated that in the United States the operational cost of a traditional bank transaction is approximately $\$ 1.07$ while the equivalent cost through telephone banking is $\$ 0.54$, and the cost of an internet banking transaction is only $\$ 0.001$ (Seshunoff, 2000; Mols, 2000), is presented in Figure I. Moreover, it is also evident from previous research that, apart from being the most profitable service delivery channel of banking institutions, internet banking also exerts the highest level of customer satisfaction and retention compared to the traditional bank branches (Adapa, 2010; Polatoglu \& Ekin, 2001).

\section{Figure I: Cost per Transaction of Various Banking Channels}

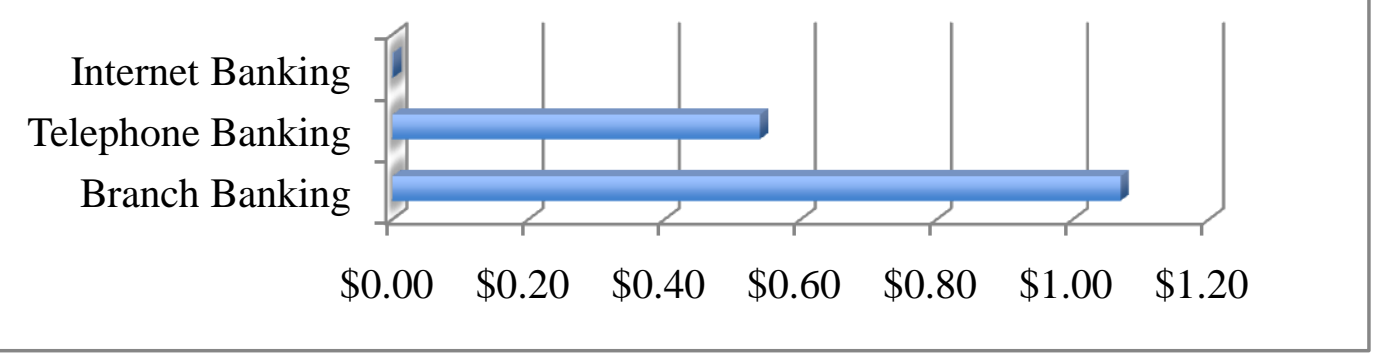

The emergence of internet banking has meant that banking activities are no longer subject to time and geographical constraints (Karjaluoto et al. 2002) as internet banking offers 24 hour accessibility to consumers (Ismail \& Panni, 2009). Gurau (2002) emphasised that internet banking services are attractive to target markets for both individual consumers and corporate clients. Lee \& Lee (2001) noted that internet banking provides easier access to bank accounts and lower service charges. Furthermore, internet banking is associated with high speed of service and lower transaction costs (Chang, 2002). The advantages associated with the internet banking channel attracted significant customer attention evident through phenomenal increase in customer's internet banking transactions. Despite these advantages, customers often switch to alternative banking channels or complement internet banking channel with other banking channels in order to carry out their banking transactions (Kolodinsky et al. 2004). The gap between the obvious advantages of internet banking and the fact that it is not the dominant method of undertaking transactions indicates that marketers, bankers and financial institutions need to make an effort to understand the factors that influence a consumer's switching behaviour and circumstances under which customers tend to switch from performing internet banking (Adapa, 2008). There are a number of internet banking studies that have investigated factors that influence a consumer's intention to adopt or their acceptance of internet banking (Gerrard \& Cunningham, 2003). However, a persistent argument is that prior studies on internet banking adoption by consumers, and the factors responsible for their adoption of the internet, have produced inconclusive and sometimes conflicting results (Adapa et al. 2009). Similarly extant literature also falls short of exploring the reasons and circumstances under which internet banking users tend to use other alternative channels of service delivery for performing their banking transactions. This has culminated in a difficulty in articulating the precise findings of internet banking research (Ndubisi \& Sinti, 2006). Thus, the findings from research on internet banking from the consumer's perspective remains unclear and in many ways impractical as it is not applied to the business context.

The growing use of technologies in services has revolutionised the interactions between service providers and customers and increased standardisation of many services (Liljander et al., 2006). The introduction of new service delivery channels increases the productivity and efficiency of the service providers apart from offering access to customers; thereby better meeting customer demand and increasing satisfaction (Walker et al. 2002). Internet banking facilitating electronic transactions is a key facilitator of communication in business activities and in consumers' day-to-day activities (McCole \& Ramsay, 2009). The decision to perform internet banking is at the consumer's discretion, indicating the importance of the consumer in electronic interactions (Adapa, 2010). It is critical for business success to understand how consumers make decisions to use internet banking' and at the same time, how marketers 
try to understand consumers' values, beliefs and preferences (Lindgreen \& Wynstra, 2005). Existing customers represent a valuable asset to the service provider. From the bank's perspective, maintaining and retaining their existing customer base is always more profitable than trying to acquire new customers (Srinivasan et al. 2002). Therefore, banks continuously scan and attempt to persuade customers not to switch to competitors in order to maximise their sales and profits (Hammond \& Ehrenberg, 1995). Customer participation has always been an indispensable part of any service delivery process (Karmarkar \& Pitbladdo, 1997). The management of the service delivery channel performance presents an unusual problem in that the performance of the service system is affected by the actions of customers who may feel uncertain about their capabilities and goals. In the past decade, the objective of most research in internet banking research has been to analyse the acceptance and adoption of internet banking service delivery channels and to understand the factors which lead to the adoption process (Chen et al. 2005). Since its introduction, internet banking, due to its speed and convenience, has been widely accepted by consumers as a service innovation (Klopping \& McKinney, 2004). In recent years, internet banking transactions increased to a greater extent, indicating the voluminous nature of transactions carried out by the internet banking consumers (Kasheir et al. 2009). This phenomenal uptake and use of internet banking, together with the internet banking experience, modifies the behaviour of individuals towards the channel (Gefen et al. 2003). Change is evident in consumers' initial perceptions and heightens the need to understand not only consumers' pre-adoption behaviour, but also post-adoption behaviour (Yu et al. 2005). Therefore, this study sets out to explore the circumstances under which internet banking consumers tend to use other banking channels for performing their banking transactions.

\section{Methodology}

A few open-ended questions relating to the qualitative data were developed alongside the quantitative scales within a general conceptual framework of continued and frequent use of internet banking by consumers within Australian context. Most of the theoretical perspectives that emerged from existing studies on internet banking research were a result of quantitative studies involving testing of questionnaire data. In order to gain an in-depth understanding of the opinions of respondents about their internet banking experience, four qualitative open-ended questions were developed. These open-ended questions were exploratory in nature and arose mostly out of the existing literature that elicits the need for qualitative responses and makes an attempt to shift the focus of the existing literature by seeking the opinions of the respondents in their own words. For the purpose of the present study primary data were collected from users as well as non-users of internet banking by a cross-sectional mall intercept survey (Adapa, 2010). Due to security issues the mall intercept survey was found to be more feasible for the researcher than conducting the survey on the bank premises. The researcher obtained permission to conduct the survey within the foyer of their shopping mall from the authorities in the Western Sydney region. The questionnaire was administered by the researcher to potential respondents who were either entering or exiting the shopping mall. Upon approaching the potential respondents and obtaining their consent to fill out the questionnaire, the researcher checked whether they were customers of the retail banks operating in Australia and are current users of internet banking or not. The questionnaires from the survey were collected over a four month period from June 2008 to September 2008 in order to obtain a valid sample. All willing volunteer respondents thus formed the total sample. The present research was conducted in the Sydney region, as it is a financial centre in Australia, as well as the location where a majority of the retail banks conduct their operations. The questionnaire was distributed to both the users and non-users of internet banking. Out of the 1308 respondents intercepted in the foyer of the shopping mall, 698 respondents answered the survey questionnaire. Of these questionnaires obtained, only 683 questionnaires were valid with complete responses, thus indicating 52.5 percent of the response rate. Among the 683 usable questionnaires, 372 were completed by users and the remaining 311 by non-users of internet banking.

Qualitative Data Analysis Approaches: Qualitative data obtained from open-ended survey responses in research often elicit new information about an experience or topic, to explain or clarify quantitative findings, and permits one to explore different dimensions of the respondent's experiences (Jackson \& Trochim 2002). Open-ended questions included in the survey offer greater anonymity to respondents and more honest responses might be provided to the researcher (Erickson \& Kaplan 2000). Moreover, they can also capture diversity in responses and provide alternate explanations to those that closed-ended survey questions are less able to capture (Pothas et al. 2001). Despite the advantages offered by the openended responses, they generate a challenging type of text to analyse. The qualitative component of the 
research will be examined using thematic matrix display tables (Miles \& Huberman 1994). The thematic matrix display tables will be presented to show responses which belong together in a conceptual sense. The frequencies of the appearance of a particular theme will also be displayed. The results of the qualitative component of the research will be presented in tables displaying counts of specific themes with a possibility of classifying them further into several micro themes. Micro themes identified will subsequently build on to macro themes.

Thematic Matrix Displays: Qualitative data analysis by thematic matrix display tables involves the four stages of data collection, data reduction, data display and data conclusion (Miles \& Huberman 1994).Qualitative data will be collected from the respondents with the help of the four open-ended questions included in the questionnaire. Qualitative data will be obtained from both the users and nonusers of internet banking in stage one data collection phase (Adapa et al. 2009). Data reduction typically means summarising or coding large amounts of text into smaller amounts of text and often involves selecting, focusing, simplifying, abstracting and transforming the raw data into summaries organised around themes or patterns based on the research objectives. Qualitative data obtained will be reduced to specific themes of importance relevant to the research in stage two data reduction phase. Data display is defined as 'an organised assembly of information' that allows conclusions to be drawn and actions to be taken (Miles \& Huberman 1994, p. 23). Matrices, graphs, networks and charts are used frequently to present information in compact forms for the purpose of the data accessibility. Thematic matrix display tables will be used to display data in order to support further illustrations and conclusions in stage three data display phase. Data conclusion refers to the process of deciding what things mean, noting themes, patterns, regularities and explanations (Miles \& Huberman 1994). Preliminary conclusions will be drawn at stage four data conclusion phase. The present study focuses on the aspect that qualitative data analysis will be a continuous and iterative process. It helps the researcher to classify the key themes and relationships that emerged from the analysis (Adapa, 2010). For further meaningful interpretationof the data under consideration, an interactive model will be developed which will permit comparisons of the findings obtained from the qualitative data analysis with the findings obtained from the quantitative data analysis.

Descriptive Statistics of the Sample: The frequencies and valid percent (percent excluding any missing responses) of internet banking users from the total respondents are presented in Table I. The overall response rate obtained from the survey was 52.5 percent. Completed surveys were received from 683 respondents of which 372 were internet banking users (54.5\%) and 311 were non-users of internet banking (45.5\%).

Table 1: Frequencies of the Internet Banking Users and Non-users

\begin{tabular}{llll}
\hline Item & Characteristic & Frequency & Percentage \\
\hline Internet Banking & Users & 372 & 54.5 \\
& Non-users & 311 & 45.5 \\
& Total & 683 & 100.0 \\
\hline
\end{tabular}

Demographic Profile of Internet Banking Users: The demographic profile of the participants who responded to the survey as internet banking users is shown in Table II. From the table it is evident that there were more males (53.8\%) in the sample of internet banking users than females. Maximum numbers of the respondents identified were within the age range of 31 to 40 years as internet banking users represented as $28.2 \%$ respectively. The majority of the internet banking users had attained a higher education level. Internet banking users (21.2\%) were within the income range of $\$ 80001$ and over. Most internet banking users were of Asian ethnicity (23.7\%) in the sample. Maximum numbers of the respondents as internet banking users were derived from the managerial occupation (30.1\%).

\section{Objectives of the Qualitative Data Analysis}

For the purpose of this research paper, data collected from only one qualitative open-ended question was analysed and discussed. The objectives of the qualitative research was to obtain answers from the respondents regarding circumstances which prompt them to use other service delivery channels specifically with internet banking usage. Miles \& Huberman (1994, p. 41), assert that qualitative data can help to validate, interpret, clarify and illustrate quantitative findings, as well as strengthen and revise theory. Similarly, Collis \& Hussey (2003) suggest that it is advantageous to use qualitative research methods, as the qualitative data provides 'insights and illuminations' to the findings obtained from the 
quantitative data (Adapa, 2010). Responses were obtained from open-ended question as a deliberate attempt towards 'focusing and bounding' the research. Inclusion of an open-ended question at the end of the questionnaire was an attempt to engage respondents' free flowing opinions that was posited by Miles \& Huberman (1994, p. 17), suggesting this method as 'a tighter research design akin to "confirmatory", seeking to test and further explicate the conceptualization' of the topic under consideration. The openended question asks the respondents 'As an internet banking user, under what circumstances do you use other ways to conduct your banking transactions?'

Table 2: Demographic Profile of Internet Banking Users

\begin{tabular}{llll}
\hline Item & Characteristic & \multicolumn{2}{l}{ Internet Banking Users } \\
\cline { 3 - 4 } Gender & Male & Frequency & Percentage \\
& Female & 172 & 53.8 \\
& $18-21$ & 16 & 46.2 \\
& $22-25$ & 50 & 4.3 \\
& $26-30$ & 65 & 13.4 \\
& $31-40$ & 105 & 28.5 \\
& $41-50$ & 80 & 21.5 \\
& 51-60 & 37 & 9.9 \\
Education & 61 or over & 19 & 5.1 \\
& Primary School & 1 & 0.3 \\
& Secondary School & 65 & 17.5 \\
& Vocational Education and Training & 67 & 18.0 \\
& Higher Education & 239 & 64.2 \\
& \$20 000 and under & 44 & 11.8 \\
& \$20 001-\$35 000 & 46 & 12.4 \\
& \$35001-\$50 000 & 70 & 18.8 \\
& \$50 001-\$65 000 & 66 & 17.7 \\
& \$65 001-\$80 000 & 67 & 18.0 \\
& \$80 001 and over & 79 & 21.2 \\
& Anglo Australian & 76 & 20.4 \\
& Asian & 88 & 23.7 \\
& English & 71 & 19.1 \\
& Middle Eastern & 53 & 14.2 \\
& New Zealand & 39 & 10.5 \\
& Others & 45 & 12.1 \\
Occupation & Student & 58 & 15.6 \\
& Manager & 112 & 30.1 \\
& Self-employed & 15 & 4.0 \\
& Administration & 41 & 11.0 \\
& Retiree & 11 & 3.0 \\
& Doctor & 17 & 4.6 \\
& Public servant & 36 & 9.7 \\
& Housewife & 11 & 3.0 \\
& Teacher & 20 & 5.4 \\
& Academic & 28 & 7.5 \\
& Community services & 14 & 3.8 \\
& Analyst & 9 & 2.4 \\
\hline
\end{tabular}


Data Preparation: Raw data obtained from the questionnaire was categorised into a series of conceptually clustered matrices. Actual responses obtained from the open-ended question included in the questionnaire were reduced to meaningful themes. Themes that were identified either supported the existing theory on internet banking research or introduced new themes specific to internet banking research in the Australian context from the consumers' perspective. The themes identified were displayed in the form of count summaries and frequencies of 'themed' responses (Adapa, 2010).

Thematic Matrix Displays: Miles \& Huberman (1994, p. 132) reported the use of conceptually clustered matrix displays while reducing data into thematically similar categories. Also Miles \& Huberman (1994, p. 127) recommended the application of thematic matrix displays where several research questions are clustered 'so that meaning can be generated more easily', and it is of primary interest when the researcher has 'a priori ideas about items that derive from the same theory or relate to the same overarching theme'. Miles and Huberman (1994, p. 127) also reported the possible occurrence of 'conceptual coherence' when the responses given by the respondents are more or less similar. Subsequently, all the responses were manually transcribed for the analysis. Responses obtained the openended question were systematically analysed for the presence of thematically similar words and phrases. Some actual quotes in the respondent's own words, which in a broader sense indicated what the majority of the respondents had written while filling out the questionnaire, are presented.

Analysis of Responses to Open-Ended Question: Circumstances under Which Internet Banking Users Use Other Ways to Conduct Their Banking Transactions: Responses for this open-ended question were obtained from the internet banking users. From the effective sample size of 372 internet banking users contacted for the purpose of the present study 354 respondents provided valid responses explaining the circumstances under which they use other ways to conduct their banking transactions. Out of these 354 responses, 205 were from male respondents and 147 from female respondents. Moreover, 267 respondents had higher education qualifications and 283 respondents were in the managerial occupation. Furthermore, 198 of the respondents specified their level of income was within the range of $\$ 65001$ to $\$ 80000$.

Content-Analytic Summary Table Displaying Circumstances under which Internet Banking Users use other ways to conduct their Banking Transactions: The second and third columns presented in Table III display a hierarchy of macro and micro thematic categories that emerged from the analysis of responses regarding 'circumstances under which internet banking users use other ways to conduct their banking transactions'. The macro and micro themes enumerated are enhanced by brief actual quotations obtained from the respondents displayed in the fourth column of the Table III. The number of times a certain response was mentioned by the respondents is presented in the parentheses.

Table 3: Conceptually-clustered Matrix Display: Circumstances Under which Internet Banking Users Use other Ways to Conduct their Banking Transactions ${ }^{\text {a }}$

\begin{tabular}{|c|c|c|c|}
\hline Number & Macro theme & Micro theme & Responses \\
\hline \multirow[t]{4}{*}{1} & $\begin{array}{l}\text { Unable to } \\
\text { perform over } \\
\text { the internet } \\
(218)\end{array}$ & $\begin{array}{l}\text { Cash } \\
\text { withdrawals }\end{array}$ & $\begin{array}{l}\text { "cash cannot be withdrawn / unable to do cash } \\
\text { withdrawals / ready cash cannot be dispensed from } \\
\text { internet banking / ready cash not available and } \\
\text { withdrawn" (163) }\end{array}$ \\
\hline & & $\begin{array}{l}\text { Deposit } \\
\text { cheques }\end{array}$ & $\begin{array}{l}\text { "cheques cannot be deposited / depositing cheques not } \\
\text { possible / cannot deposit cheques / no cheque deposit } \\
\text { facility" (30) }\end{array}$ \\
\hline & & $\begin{array}{l}\text { Overseas } \\
\text { transactions }\end{array}$ & $\begin{array}{l}\text { "overseas transactions cannot be performed on a full } \\
\text { scale / overseas transactions need to be done in the } \\
\text { bank / overseas transactions cannot be completed / } \\
\text { overseas transactions require assistance from bank } \\
\text { staff" (18) }\end{array}$ \\
\hline & & Money orders & $\begin{array}{l}\text { "money orders cannot be processed / sending money } \\
\text { orders is difficult / need to go to bank branch to } \\
\text { process money orders" (7) }\end{array}$ \\
\hline 2 & $\begin{array}{l}\text { Lack of internet } \\
\text { access (68) }\end{array}$ & Travel & $\begin{array}{l}\text { "while travelling internet access may not be available } \\
\text { all the time / when travelling prefer to use ATM / } \\
\text { accessing internet is difficult during travel" (43) }\end{array}$ \\
\hline & & Server & 'banks' site problems cause lack of proper access / \\
\hline
\end{tabular}




\begin{tabular}{|c|c|c|c|}
\hline Number & Macro theme & Micro theme & Responses \\
\hline \multirow{6}{*}{3} & \multirow{6}{*}{$\begin{array}{l}\text { Not sure of } \\
\text { something (38) }\end{array}$} & problems & $\begin{array}{l}\text { servers might be down at times / server site may } \\
\text { create problems and slow down accessing internet } \\
\text { transactions" (11) }\end{array}$ \\
\hline & & $\begin{array}{l}\text { Internet speed } \\
\text { is slow }\end{array}$ & $\begin{array}{l}\text { "sometimes internet speed may be slow / if speed of } \\
\text { the internet is not fast enough preference may orient to } \\
\text { other channels" (9) }\end{array}$ \\
\hline & & $\begin{array}{l}\text { Failure in the } \\
\text { power }\end{array}$ & $\begin{array}{l}\text { "though rare, power failure encourages to use other } \\
\text { banking channels / cannot access internet when there } \\
\text { is a power failure" (5) }\end{array}$ \\
\hline & & $\begin{array}{l}\text { Introduction of } \\
\text { new products } \\
\text { or services }\end{array}$ & $\begin{array}{l}\text { "when innovative products are introduced and not } \\
\text { sure of a decision prefer to go to bank to get more } \\
\text { detailed information / prefer to talk to bank personnel } \\
\text { when new products are introduced by the bank and } \\
\text { not sure of something" (25) }\end{array}$ \\
\hline & & $\begin{array}{l}\text { Dealing with } \\
\text { major loans }\end{array}$ & $\begin{array}{l}\text { "major investment decisions such as mortgage loan, } \\
\text { personal loan etc., prefer to go to bank to make sure } \\
\text { everything is alright and not sure of some aspects / } \\
\text { dealing with big loans prefer to go to bank / vast } \\
\text { investments and loans prefer to talk to bank personnel } \\
\text { when cannot make a decision by myself and not sure of } \\
\text { something" (10) }\end{array}$ \\
\hline & & $\begin{array}{l}\text { Change } \\
\text { website } \\
\text { functions }\end{array}$ & $\begin{array}{l}\text { "any changes in the website and unclear instructions } \\
\text { leads to the bank" (3) }\end{array}$ \\
\hline 4 & $\begin{array}{l}\text { Problem } \\
\text { rectification } \\
(23)\end{array}$ & $\begin{array}{l}\text { Regular } \\
\text { transactions }\end{array}$ & $\begin{array}{l}\text { "if any problems arise in regular bill payments such as } \\
\text { rental, electricity etc., for clarification prefer to go to } \\
\text { bank / any overpayments or underpayments in } \\
\text { performing regular transactions prefer to talk to bank } \\
\text { staff" (18) }\end{array}$ \\
\hline \multirow{3}{*}{5} & \multirow{3}{*}{$\begin{array}{l}\text { Proximity } \\
\text { auxiliary } \\
\text { facilities (7) }\end{array}$} & $\begin{array}{l}\text { Rare } \\
\text { transactions }\end{array}$ & $\begin{array}{l}\text { "internet purchasing and payments made over internet } \\
\text { at times create problems that need to be corrected / } \\
\text { rarely internet shopping and related payments create } \\
\text { transaction problems" (5) }\end{array}$ \\
\hline & & $\begin{array}{l}\text { Computer } \\
\text { location }\end{array}$ & $\begin{array}{l}\text { "at home, computer is located upstairs and if the } \\
\text { location of telephone is convenient, prefer to perform } \\
\text { phone banking / access to computer if restricted prefer } \\
\text { to perform transactions over other channels" (5) }\end{array}$ \\
\hline & & $\begin{array}{l}\text { Type of } \\
\text { internet } \\
\text { connection }\end{array}$ & $\begin{array}{l}\text { "do not have broadband connection at home and the } \\
\text { preference is for phone banking / dial-up connection at } \\
\text { home is slow to do banking transactions and perform } \\
\text { most of the banking transactions at office as broadband } \\
\text { connectivity is really fast" (2) }\end{array}$ \\
\hline
\end{tabular}

a Number of respondents mentioning a micro theme is provided in the parentheses categorised against a macro theme.

Analysis of 'Macro' and 'Micro' Themes: Table IV further provides the count and percentages of the macro and micro themes. In the second and third columns, the hierarchy of macro and micro thematic categories is enumerated. The fourth and fifth columns display the actual count and percentages of each macro and micro themes identified.

Table 4: Macro and Micro Theme Counts and Percentages: Circumstances Under which Internet Banking Users Use other Ways to Conduct their Banking Transactions

\begin{tabular}{lllll}
\hline Number & Macro theme & Micro theme & Count & Percentage \\
\hline 1 & $\begin{array}{l}\text { Unable to perform } \\
\text { over the internet }\end{array}$ & Cash withdrawals & 163 & $\mathbf{6 1 . 6}^{\mathrm{a}}$ \\
& & & $\mathbf{2 1 8}$ & $74.8^{\mathrm{b}}$
\end{tabular}


Table 4: Macro and Micro Theme Counts and Percentages: Circumstances Under which Internet Banking Users Use other Ways to Conduct their Banking Transactions

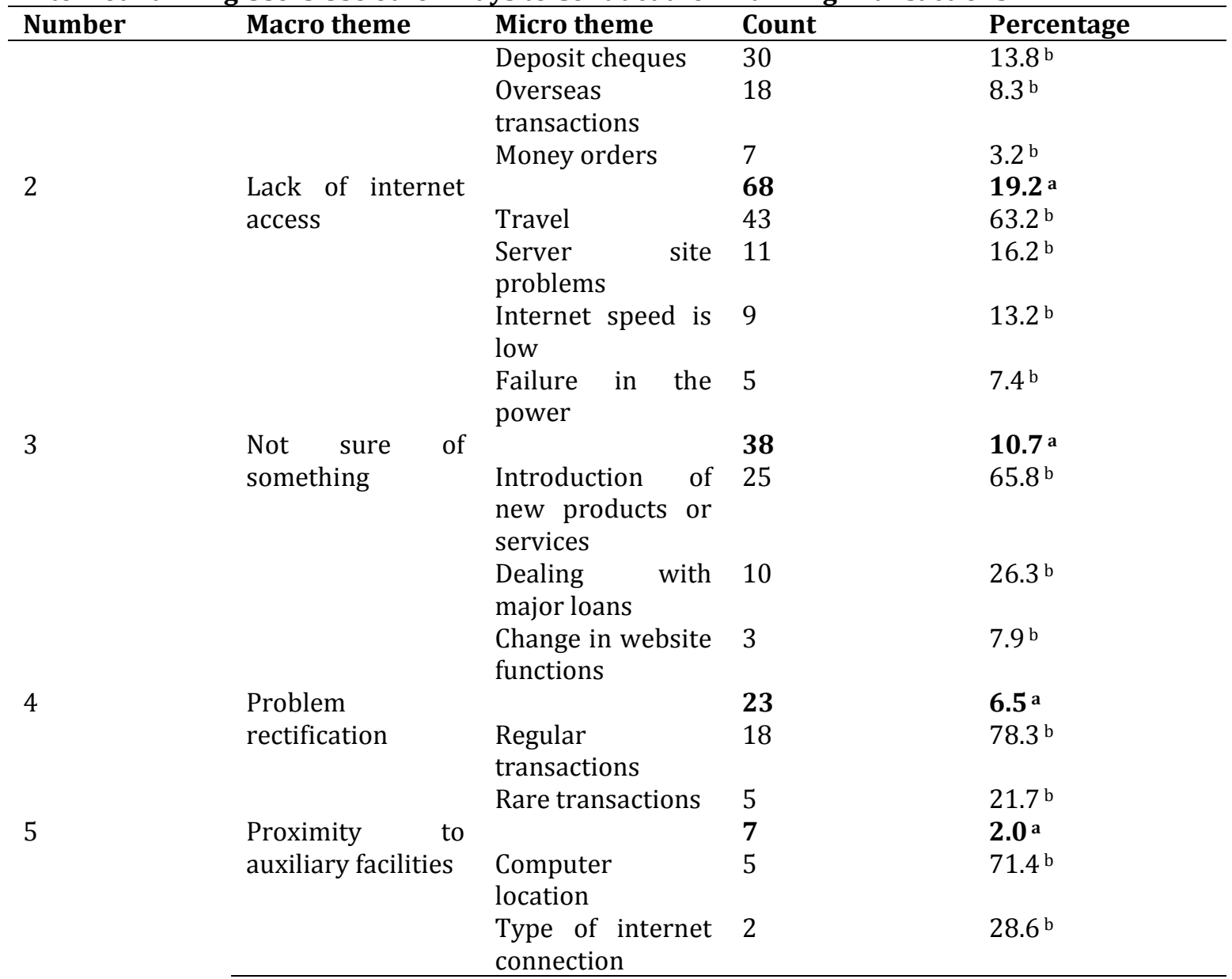

a Macro theme percentage is out of all responses

${ }^{b}$ Micro theme percentages are out of all responses for their respective macro theme

Five 'macro' themes were identified, each comprised of several more specific micro themes. The first macro theme, 'unable to perform over the internet', subsumed four micro themes. The most prevalent micro themes in descending order were cash withdrawals, deposit cheques, overseas transactions and money orders. The macro theme, 'unable to perform over the internet', relates to the inability of the respondents to perform certain banking transactions over the internet. Actual counts indicated 'cannot perform cash withdrawals', 'unable to deposit cheques', 'overseas transactions are difficult to perform over the internet', and 'cannot process money orders'. Lack of the abovementioned facilities over the internet encourages internet banking users to approach and use other modes of service delivery at relevant circumstances to meet their banking needs and requirements effectively.

'Whenever ready cash is required I prefer to go to ATM and withdraw cash' (Respondent \# 2

'Cash cannot be withdrawn through internet banking, so I look for ATM for ready cash' (Respondent \# 192).

'As part of my job, I need to deposit cheques more often. As this facility is not available with internet banking, I prefer to go to bank branch' (Respondent \# 201).

'My extended family lives in overseas. Overseas transactions are not so easy to perform over the internet. I need to go to bank to do my overseas-related transactions' (Respondent \# 94).

'To process money orders I go to bank as internet banking cannot do that' (Respondent \# 71).

The second macro theme identified was 'lack of internet access' which subsumed four micro themes. Based on the number of counts the most prevalent micro themes in a hierarchical order were travel, server site problems, internet speed is low and failure in the power. Actual responses refer to 'no internet access during travel', 'server sites at times are problematic to access internet', 'internet speed is not fast delaying internet access' and 'though rare, power failure relates to lack of internet access'. Circumstances 
such as those mentioned above require internet banking users to use other available alternative modes of service delivery channels.

'Whenever I travel I prefer to use ATM rather than internet for my personal banking' (Respondent \# 39).

'Getting proper internet access during travel is difficult and my preference is to use ATM' (Respondent \# 234).

'At times the server sites are problematic which might reduce the speed of internet accessibility' (Respondent \# 312).

'Internet access could be impeded sometimes which reduces the internet speed and makes internet banking difficult' (Respondent \# 65).

'Though rare, internet cannot be accessed when there is a failure in the power which obstructs my banking transactions over the internet. I look for feasible alternatives' (Respondent \# 29).

In a hierarchical order, the third macro theme identified was 'not sure of something'. The third macro theme subsumed three micro themes of introduction of new products or services, dealing with major loans and change in website functions based on the counts in descending order. Actual responses include 'not sure of something when new products are introduced', 'not sure of something when dealing with major investments and loans', and 'not sure of something when there is a change in website related functions'. The abovementioned micro themes are mostly situation specific and most of the respondents indicated that when they are faced with these specific situations they prefer to go to the bank and clarify with the bank personnel.

'Banks frequently introduce innovative products and services. When I am not sure of something I prefer to go to the bank and deal with the staff there to resolve the issue' (Respondent \# 77).

'Particularly dealing with housing loans I prefer to talk to the concerned bank personnel and make sure that everything is clear for me' (Respondent \# 328).

'Dealing with major investments and loans on a personal level I prefer to make sure with the bank that everything is clarified to me' (Respondent \# 35).

'When my bank makes changes to its existing website features and if I am not sure of something, I prefer to speak to the bank staff for clarification' (Respondent \# 59).

The fourth macro theme relates to 'problem rectification'. Based on the counts available to this macro thematic category, it subsumed two micro themes. In order of prevalence these micro themes were regular transactions and rare transactions. Actual responses refer to 'rectifying problems associated with regular bill payments', 'correcting over or under payments related to the bills on a regular basis', 'correcting problems associated with internet purchasing rarely' and 'problem rectification while performing internet shopping less frequently'. Thus regular transactions were associated with overpayment or underpayment of the bills over the internet. On the contrary, rare transactions were related to internet purchasing and internet shopping. Respondents evidently indicated that when potential problems arise on a regular or rare basis for rectifying those problems, they prefer to go to the bank.

'I purchased sports shoe over the internet and paid the amount charged through internet banking using my credit card. Payment was not received by the vendor. And I need to go to the bank to fix this problem' (Respondent \# 4).

'I usually pay all my regular bills over the internet using internet banking. Once there was an overpayment and to rectify this problem I have to go to the bank and talk to the staff there' (Respondent \# 87).

The last macro theme identified was 'proximity to auxiliary facilities'. The most prevalent micro themes associated with the macro theme proximity to auxiliary facilities were computer location and type of internet connection in descending order. Actual respondents counts relate to 'location of computer distantly and proximity to telephone' and 'dial-up connection being slow and proximity to telephone'. Problems associated with the location and type of connection of primary facilities such as computer and internet encourages internet banking users to perform their transactions using other modes. All the respondents indicated their preference to use telephone banking in the absence of primary facilities and proximity to an auxiliary facility such as availability of the telephone. 
'My computer at home is located upstairs and at times I prefer to use phone banking as telephone is conveniently located in the living room' (Respondent \# 247).

'I usually perform internet banking from my office as internet speed is fast with broadband connection. At home I have dial-up connection. If I need to perform any banking transactions while at home, I prefer to use telephone banking' (Respondent \# 63).

Discussion: The qualitative findings obtained from the internet banking users for the open-ended question, circumstances under which internet banking users use other methods for performing their banking transactions, resulted in the five macro thematic categories of 'unable to perform over the internet', 'lack of internet access', 'not sure of something', 'problem rectification' and 'proximity to auxiliary facilities'. The macro thematic category 'unable to perform over the internet' revealed micro themes of cash withdrawals, depositing cheques, overseas transactions and dealing with money orders. As consumers are unable to perform cash and cheque withdrawals and deposits over the internet as well as transactions dealing with overseas and money orders, a majority of the internet banking users prefer either ATMs or branch banks to suit their requirement. 'Lack of internet accesses identified as another macro thematic category showed travel, server site problems, slow internet speed and power failure as micro themes. All these micro themes identified were situation specific and asserts the importance of considering situation variables in internet banking research in future. The macro thematic category 'not sure of something' consisted of the micro themes of introduction of new products and services, dealing with major loans and change in website functions. Thus, if internet banking users are 'not sure of something' they prefer to use other banking channels. 'Problem rectification', identified as a macro thematic category, showed regular and rare transactions as micro themes.

Thus, internet banking users, if faced with a problem while performing either regular or rare transactions, prefer to use other banking channels (most probably branch banks) in order to rectify the problem. Location of the computer and type of internet connectivity were the micro themes identified for 'proximity to auxiliary facilities' macro thematic category in this research. Thus, internet banking users prefer to use other banking channels based on the proximity to auxiliary facilities. The open-ended question circumstances under which internet banking users prefer to use other banking channels is exploratory in nature and the thematic categories identified are context specific, eliciting the importance and incorporation of situation specific variables in internet banking research. Therefore, this piece of research highlights the nature of situational variables and their influence in motivating internet banking users to switch to alternative channels to perform their banking transactions. The results obtained from this study also provide important implications for retail banking managers in formulating their channel management strategies and thus focusing on the retention of various segments of customers through banking needs. Retail banking managers may need to work closely with the internet service providers in designing bundled offers that are beneficial to all of the stakeholders involved in order to have maximum customer retention towards their internet banking channel.

\section{Conclusion}

This research highlights the circumstances under which internet banking users switch to use an alternative channel to perform their banking transactions. Macro and micro thematic categories of importance were identified in that order of hierarchical influence. These emerged thematic categories tend to be situational and the recommendations provided highlight that retail banking managers need to work closely with the internet service providers for the benefit of all of the stakeholders involved as well as for the maximum customer retention. A comparison analysis of identifying the similar circumstances under which customers switch from physical branch banking to electronic banking channels would shed some light in eliciting themes of importance. Drawing on cross-cultural or ethnicity comparisons can also further extend this study.

\section{References}

Adapa, S. (2010). Macro and micro thematic categories hindering customer adoption of internet banking in Australian context. ANZMAC Conference, 29 $9^{\text {th }}$ November - $1^{\text {st }}$ December, Christchurch, New Zealand.

Adapa, S., Rindfleish, J., Cooksey, R. \& Valenzuela, F. (2009). Dimensions affecting consumers' continued usage and frequency of usage of internet banking: Empirical evidence from Australia. GABERIC Conference, $28^{\text {th }}-30^{\text {th }}$ December, Kuala Lumpur, Malaysia. 
Adapa, S. (2008). Consumer's evaluation of electronic banking service delivery channels and impact on banking provider. UNE Postgraduate Research Conference, $15^{\text {th }}-18^{\text {th }}$ July, Armidale, Australia.

Adapa, S. (2008). Customer perceived value of internet banking in Australian context: A conceptual model development. ANZMAC Conference, $1^{\text {st }}-3^{\text {rd }}$ December, Sydney, Australia.

Akinci, S., Akoy, S. \& Atilgan, E. (2004). Adoption of internet banking among sophisticated consumer segments in an advanced developing country. International Journal of Bank Marketing, 22(3), 212-232.

Chang, Y. (2002). Dynamics of banking technology adoption: An application to internet banking. Working paper, University of Warwick.

Chen, T. Y., Chang, P. L. \& Chang, H. S. (2005). Price, brand cues, and banking customer value. International Journal of Bank Marketing, 23(3), 273-291.

Collis, J. \& Hussey, R. (2003). Business Research: A Practical Guide for Undergraduate and Postgraduate Students (2 $2^{\text {nd }}$ Ed.). Palgrave Macmillan, Hampshire, England.

Daniel, E. (1999). Provision of electronic banking in the UK and the Republic of Ireland.International Journal of Bank Marketing, 17(2), 72-82.

Durkin, M. (2004). In search of the internet banking customer, exploring the use of decision styles. International Journal of Bank Marketing, 22(7), 484-523.

Durkin, M., Jennings, D., Mulholland, G. \& Worthington, S. (2008). Key influencers and inhibitors on adoption of the internet for banking. Journal of Retailing and Consumer Services, 15, 348-357.

Erickson, P. I. \& Kaplan, C. P. (2000). Maximising qualitative responses about smoking in structured interviews. Qualitative Health Research, 10, 829-840.

Gefen, D., Karahanna, E. \& Straub, D. W. (2003). Trust and TAM in online shopping: An integrated model. MIS Quarterly, 27(1), 51-90.

Gerrard, P. \& Cunningham, J. B. (2003). The diffusion of internet banking among Singapore consumers. International Journal of Bank Marketing, 21(1), 16-28.

Giglio, V. (2002). Privacy in the world of cyberbanking: Emerging legal issues and how you are protected. The Security Lender, March/April, 48-60.

Gurau, C. (2002). E-banking in transition economies: The case of Romania. Journal of FinancialServices Marketing, 6(4), 362-379.

Hammond, K. \& Ehrenberg, A. (1995). Heavy buyers: How many do you have? How important are they? Proceedings of the 24th Annual Conference of the European Marketing Academy, 1651-1655.

Ismail, H. B. \& Panni, M. F. A. K. (2009). Factors affecting customer retention toward internet banking in Malaysia. Journal of Information and Knowledge Management, 8(1), 35-43.

Jackson, K. M. \& Trochim, W. M. K. (2002). Concept mapping as an alternative approach for the analysis of open-ended survey responses. Organisational Research Methods, 5(4), 307-336.

Karjaluoto, H., Mattila, M. \& Pento, T. (2002). Electronic banking in Finland: Consumer beliefs and reactions to a new delivery channel. Journal of Financial Services Marketing, 6(4), 346-361.

Karmarkar, U. S. \& Pitbladdo, R. C. (1997). Quality, class, and competition. Management Science, 43(1), 2739.

Kasheir, D., Ashour, A. S. \& Yacout, O. M. (2009). Factors affecting continued usage of internet banking among Egyptian customers. Communication of the IBIMA, 9, 1943-7765.

Kerem, K., Lustsik, O., Sorg, M. \& Vensel, V. (2003). The development of e-banking in a EU candidate country: An Estonian case. Proceedings of International Atlantic Economic Society Conference, Vienna, March 11-17.

Klopping, I. M. \& McKinney, E. (2004). Extending the technology acceptance model and the task technology fit model to consumer e-commerce. Information Technology, Learning, and Performance Journal, 22(1), 35-48.

Kolodinsky, J. M., Hogarth, J. M. \& Hilgert, M. A. (2004). The adoption of electronic banking technologies by US consumers. International Journal of Bank Marketing, 22(4), 238-259.

Lee, E. \& Lee, J. (2001). Consumer adoption of internet banking: Need-based and/or skill based? Marketing Management Journal, 2(1).

Liljander, V., Gillberg, F., Gunmerus, J. \& Riel, A. V. (2006). Technology readiness and the evaluation and adoption of self-service technologies.Journal of Retailing and Consumer Services, 13, 177-191.

Lindgreen, A. \&Wynstra, F. (2005). Value in business markets: What do we know? Industrial Marketing Management, 34, 732-748.

McCole, P. \& Ramsey, E. (2009). A profile of adopters and non-adopters of ecommerce in SME professional service firms. Australasian Marketing Journal, 13, 36-45.

Mia, M. A. H., Rahman, M. A. \& Uddin, M. M. (2007). E-Banking evolution, status and prospects. The Cost and Management, 35(1), 36-48. 
Miles, M. B. \& Huberman, A. M. (1994). Qualitative Data Analysis: An Expanded SourceBook (2 ${ }^{\text {nd }}$ Ed.). Sage Publications, Thousand Oaks, California.

Mols, N. P. (2000). The internet and services marketing: The case of Danish retail banking. Internet Research: Electronic Networking Applications and Policy, 10(1), 7-18.

Ndubisi, N. O. \& Sinti, Q. (2006). Consumer attitudes, system's characteristics and internet banking adoption in Malaysia. Management Research News, 29(1/2), 16-27.

Polatoglu, V. N. \& Ekin, S. (2001). An empirical investigation of the Turkish consumers' acceptance of internet banking services. International Journal of BankMarketing, 19(4), 156-165.

Pothas, A., De-Wet, A. \& De Wet, J. (2001). Customer satisfaction: Keeping tabs on the issues that matter. Total Quality Management, 12(1), 83-94.

Reid, M. (2008). Integrating trust and computer self-efficacy with technology acceptance model: An empirical assessment of customers' acceptance of banking information systems (BIS) in Jamaica. Journal of Internet Banking and Commerce, 12(3).

Robinson, T. (2000). Internet Banking: Still not a perfect marriage. Informationweek.com. April 17 th, 104106.

Seshunoff, A. (2000). Internet banking: An update from the frontlines. ABA Banking Journal, 92(1), 51-53.

Shih, Y. \& Fang, K. (2004). The use of decomposed theory of planned behaviour to study internet banking in Taiwan. Internet Research, 14(3), 213-223.

Srinivasan, S. S., Anderson, R. \& Ponnavolu, K. (2002). Customer loyalty in e-commerce: An exploration of its antecedents and consequences. Journal of Retailing, 78(1), 41-50.

Thornton, T. \& White, L. (2001). Customer orientations and usage of financial distribution channels. Journal of Services Marketing, 15(3), 168-184.

United Nations Conference on Trade and Development. (2000). E-commerce and Development Report2000. United Nations, New York \& Geneva.

VanHoose, D. (2003). E-commerce Economics. South-Western Thomson Learning, Cincinnati, Ohio.

Walker, R. H., Craig-Lees, M., Hecker, R. \& Francis, H. (2002). Technology-enabled service delivery: An investigation of reasons affecting customer adoption and rejection. InternationalJournal of Service Industry Management, 13(1), 91-106.

Winch, G. \& Joyce, P. (2006). Exploring the dynamics of building, and losing, consumer trust in B2C eBusiness. International Journal of Retail and Distribution Management, 34(7), 541-555.

Wresch, W. \& Fraser, S. (2006). Managerial strategies used to overcome technological hurdles: A review of e-commerce efforts used by innovative Carribean managers. Journal of Global Information Management, 14(3), 1-16.

Yu, J., Ha, I., Choi, M. \& Rho, J. (2005). Extending the TAM for a t-commerce. Information and Management, 42(7), 965-976. 